\title{
Arizona State University Orange Mall Green Infrastructure Project Methods
}

\author{
Research Fellow: \\ Chingwen Cheng PhD, ASLA, PLA, LEED AP \\ Assistant Professor of Landscape Architecture \\ Arizona State University \\ Research Assistant: \\ Amanda Trakas \\ Masters of Landscape Architecture Candidate \\ Arizona State University \\ Firm Liaison: \\ Allison Colwell \\ Landscape Architect \\ Colwell Shelor Landscape Architecture
}

This investigation was conducted as part of the Landscape Architecture Foundation's 2020 Case Study Investigation (CSI) program. CSI matches faculty-student research teams with design practitioners to document the benefits of exemplary high-performing landscape projects. Teams develop methods to quantify environmental, social, and economic benefits and produce Case Study Briefs for LAF's Landscape Performance Series.

To cite:

Cheng, Chingwen, and Amanda Trakas. "Arizona State University Orange Mall Green Infrastructure Project." Landscape Performance Series. Landscape Architecture Foundation, 2020. https://doi.org/10.31353/cs1641

The full case study can be found at: https://landscapeperformance.org/case-study-briefs/ASUOrange-Mall 


\section{Acknowledgements}

We would like to thank Norman Yatabe, PLA, Project Manager, Office of University Architect, Arizona State University, as the key personnel for promoting landscape performance and SITES certification for this project.

Providing additional information and consultancy for CSI:

Allison Colwell and Nathanial Kirby of Colwell Shelor

Leslie Kland of KLAND Engineering

Cindy Quinn of Ecological Environments

Hydrological and ecological monitoring support provided by CAP LTER

Initial funding from Herberger Institute for Design and the Arts, Arizona State University

\section{Research Strategy}

Green infrastructure (Gl) designed for on-site stormwater management has been implemented and studied widely in the humid/semi-humid climatic regions in the US such as Seattle, Portland, New York, and Chicago. Hot and arid regions such as the Phoenix metro area have only recently begun to implement GI or low-impact design for stormwater management, and there is a growing need to understand its performance in this climate. Integrated into a large public university campus, the Orange Mall GI Project provides a critical example of how a campus landscape can be utilized as a learning laboratory for research, education, and public outreach on GI interventions. Research conducted on the Arizona State University (ASU) campus for Sustainable SITES certification along with landscape performance monitored onsite have been utilized in the creation of this case study of Orange Mall. Lessons learned from the creation and ongoing performance of the landscape have been applied to subsequent GI projects on the ASU campus and will continue to inform regional considerations for sustainable and resilient landscape design within the built environment.

\section{Environmental Benefits}

- Directs $100 \%$ of runoff from a 10 -year-storm through a series of biodetention and retention areas and on to an offsite infiltration well that recharges groundwater. The site has been observed managing stormwater volumes equivalent to a 25-year storm without overtopping.

Background: Arizona State University (ASU) began as Territorial Normal School in 1885 and dedicated their first building - Old Main - in $1898^{1}$ on what is today's ASU's Tempe campus. In the 
past 122 years, the campus has grown from a small teaching and agricultural college to one of the largest public universities in the United States, offering more than 800 undergraduate and graduate degrees, and certificates in a wide range of academic disciplines ${ }^{2}$. As the campus has added additional facilities or remodeled existing ones, careful consideration of the existing watershed has been necessary to ensure the adequate management of stormwater. Although the Lower Colorado River Valley biome of the Sonoran Desert receives a relatively low annual rainfall average of 8 inches per year, ${ }^{3}$ it is concentrated during the monsoon seasons via sporadic yet intense storm events.

The two-acre Orange Mall GI Project serves as a pilot project and key drainage point for an 18acre watershed extending north from Orange Mall across the campus (Figure 1-1). The scope of the project was to offer additional stormwater management capacity to alleviate stormwater drainage capacity from the site; it was not intended to address existing drainage issues in the watershed area. The management of stormwater was achieved through a series of Gl design interventions allowing on-site stormwater conveyance, infiltration, and retention. The Gl design, including a series of biodetention basins connected through open runnels, were integrated into an existing stormwater management system that terminates in a large infiltration dry well under an athletic field south of the site via underground pipes. The site was designed to fully manage a 10 -yr storm event. This report, completed by the civil engineer of the project, was compared to post-construction performance evaluation completed in 2018 by Chris Sanchez in his thesis for the fulfillment of the degree in the Master of Science in Sustainability at Arizona State University.

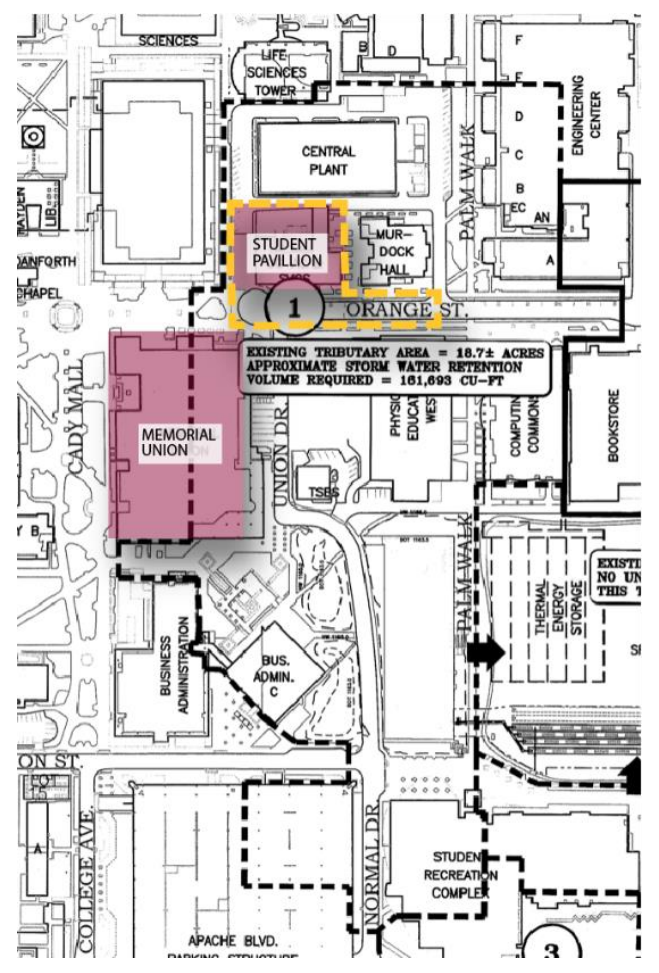

Figure 1-1: Orange Mall Watershed Map on ASU Campus. ${ }^{5}$ Orange Mall lies within an 18-acre watershed outlined with the black dashed line. The Orange Mall GI Project encompasses a 2-acre site of this watershed outlined in gold. 
Method: In the drainage letter prepared for Arizona State University, the project's civil engineer calculated maximum discharge for each biodetention basin for different storm intensities using the rational method and NOAA Atlas 14, vol 1, vers 5 for intensity ${ }^{4}$ (Figure 1-2 and Figure 1-5).

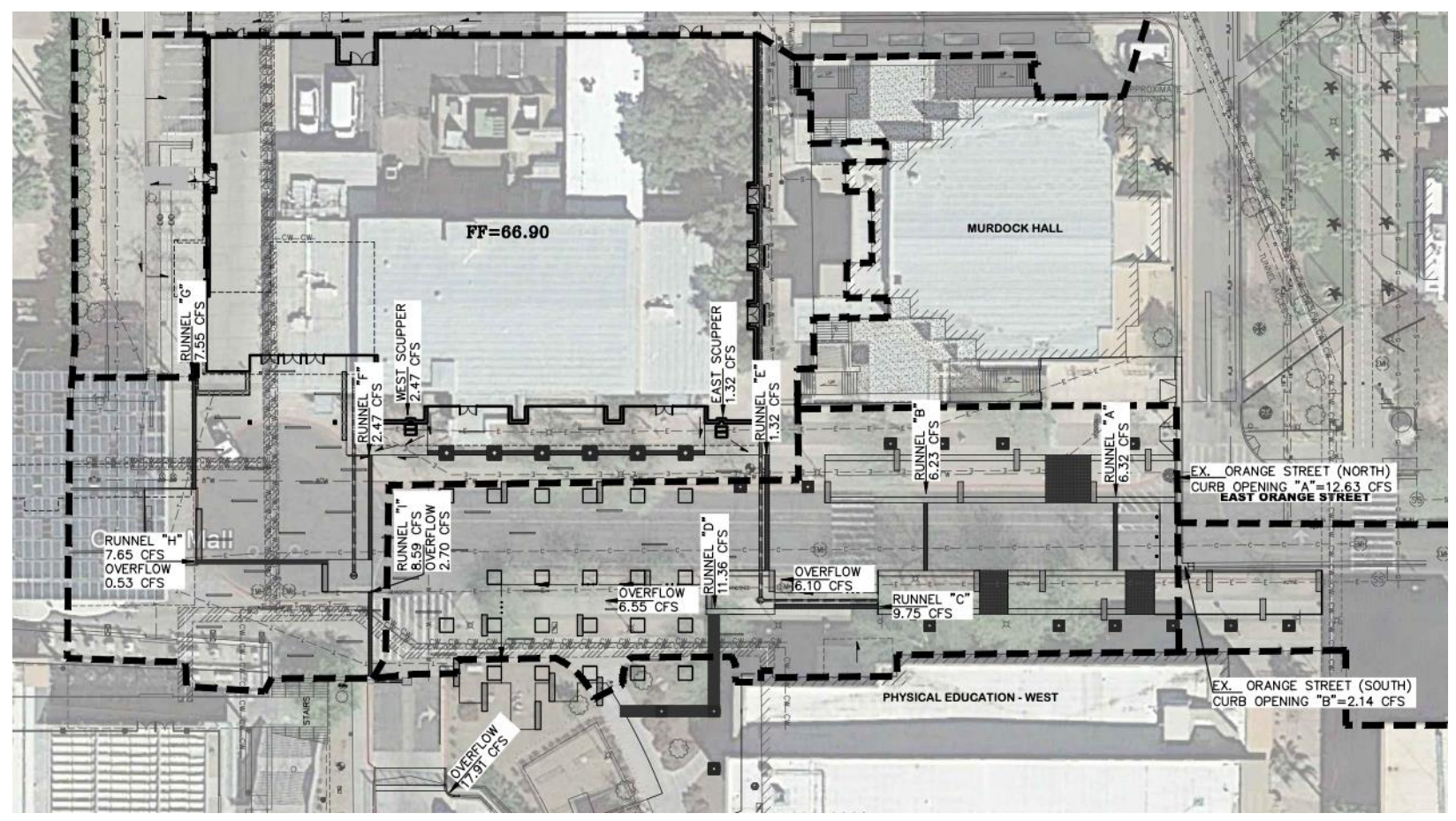

Figure 1-2: Runnel and inlet discharge calculations and locations for biodetention basins. Runnel "D" represents the outflow discharge point where post-construction monitoring data was collected by Sanchez (2019). Prepared by Kland Engineering for Orange Mall drainage report, provided by Colwell Shelor Landscape Architecture.

Post construction site performance was monitored by Sanchez over a 7-month study period from August 2018 to February 2019 to determine the quantity of stormwater managed by the site $^{5}$ (additional performance metrics described in Case Study Brief "Educational Impact" tab). 90-degree v-notch weirs that Sanchez constructed along with ONSET HOBO U20L water level probes were installed at the outflow discharge points between biodetention basins on site (see Figure 1-2 and 1-5 for east basin location details for comparison with engineer projections). The US Bureau of Reclamation Cone equation for $v$ notched weirs was used to calculate discharge rates at the weirs using these water level measurements:

$$
\mathrm{Q}=2.49^{*} \mathrm{~h} 1 * 2.48
$$

where $\mathrm{Q}$ represents the flow rate in $\mathrm{m} 3 / \mathrm{s}$, and $\mathrm{h} 1$ represents the hydraulic head on the weir. Hydraulic head was derived by subtracting the total distance from the bottom of the channel to the bottom of the weir v-notch from the observed water stage. The resulting value represents the hydrological head of water overtopping the weir.

The next section will compare the estimated maximum stormwater discharge capacity for Runnel D calculated by the civil engineer and the post-construction performance data collected 
by Sanchez.

Calculations: Out of the 17 total storm events that occurred during the Sanchez study period, only four fully inundated the basins to activate the stormwater sensors to produce stormwater quantity data (Figure 1-3).

\begin{tabular}{cccccc}
\hline Storm ID & Date & $\begin{array}{c}\text { Total Precip } \\
(\mathrm{mm})\end{array}$ & $\begin{array}{c}\text { Total Precip } \\
(\mathrm{in})\end{array}$ & $\begin{array}{c}\text { Duration } \\
(\mathrm{h})\end{array}$ & $\begin{array}{c}\text { Intensity } \\
\left(\mathrm{mm} \mathrm{hr}^{-1}\right)\end{array}$ \\
\hline 1 & $9 / 19 / 18$ & 3.00 & 0.12 & 1 & 2.9 \\
2 & $10 / 8 / 18$ & 5.08 & 0.20 & 3 & 1.69 \\
3 & $10 / 13 / 18$ & 18.79 & 0.74 & 7 & 2.68 \\
4 & $1 / 16 / 19$ & 3.05 & 0.12 & 4 & 0.76 \\
\hline
\end{tabular}

Figure 1-3: Storm events during the performance monitoring period that activated stormwater quantity sensors. The largest event of that time period is outlined in gold, and represents the equivalent of a 25 -yr storm.

The largest storm, storm 3, had a recorded peak flow rate of approximately $.375 \mathrm{~m}^{3} / \mathrm{s}$ (Figure 14) or $13.24 \mathrm{cfs}\left(1 \mathrm{~m}^{3} / \mathrm{s}=35.31 \times 10^{10}\right)$ which is just under the designed discharge for a $25-\mathrm{yr}$ storm for the largest scupper on the east side of the site (Figure 1-5).

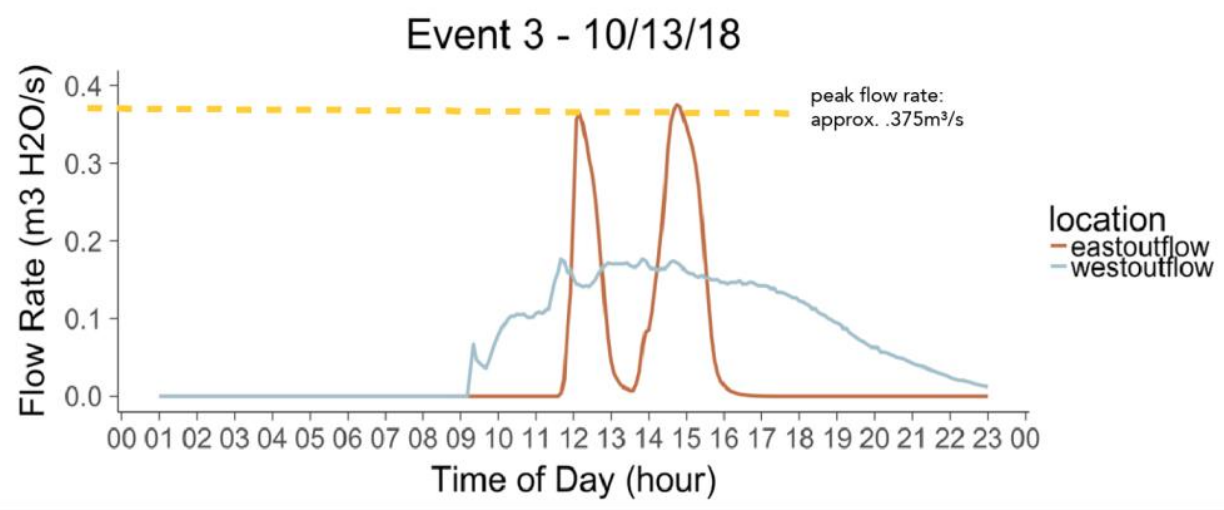

Figure 1-4: Flow Rate for Storm Event $3^{1}$ from Sanchez 2019 thesis. 


\begin{tabular}{|c|c|c|c|c|c|c|c|c|c|}
\hline \multicolumn{9}{|c|}{ Stormwater Discharge Calculations - Rational Method } & \multirow{16}{*}{$\begin{array}{l}\text { max. area of discharge } \\
\text { in bioswale system }\end{array}$} \\
\hline Discharge Location & Area & c & $\begin{array}{r}\text { Intensity } \\
(100-y r)\end{array}$ & $\begin{array}{l}\text { Discharge } \\
\text { (100-yr cfs) }\end{array}$ & $\begin{array}{l}\text { Intensity } \\
\text { (25-yr) }\end{array}$ & $\begin{array}{l}\text { Discharge } \\
\text { (25-yr cfs) }\end{array}$ & \begin{tabular}{|c|} 
Intensity \\
$(10-y r)$
\end{tabular} & $\begin{array}{l}\text { Discharge } \\
\text { (10-yr cfs) }\end{array}$ & \\
\hline Runnel "A" & 70,563 & 0.70 & 5.57 & 6.32 & 4.31 & 4.89 & 3.51 & 3.98 & \\
\hline Runnel "B" & 70,563 & 0.70 & 5.57 & 6.32 & 4.31 & 4.89 & 3.51 & 3.98 & \\
\hline Runnel "C" & 177,073 & 0.70 & 5.57 & 15.85 & 4.31 & 12.26 & 3.51 & 9.99 & \\
\hline Runnel "D" & 185,341 & 0.70 & 5.57 & \multirow{2}{*}{17.91} & 4.31 & \multirow{2}{*}{13.86} & 3.51 & \multirow{2}{*}{$\begin{array}{l}11.29 \\
-\end{array}$} & \\
\hline East Scupper & 8,268 & 0.95 & 7.32 & & 5.68 & & 4.62 & & \\
\hline Runnel "E" & 8,268 & 0.95 & 7.32 & 1.32 & 5.68 & 1.02 & $4 . \overline{62}$ & $\overline{0} . \overline{83}$ & \\
\hline Runnel "F" & 15,442 & 0.95 & 7.32 & 2.47 & 5.68 & 1.91 & 4.62 & 1.56 & \\
\hline Runnel "G" & 69,460 & 0.85 & 5.57 & 7.55 & 4.31 & 5.84 & 3.51 & 4.76 & \\
\hline Runnel "H" & 75,305 & 0.85 & 5.57 & 8.18 & 4.31 & 6.33 & 3.51 & 5.16 & \\
\hline Runnel "I" & 81,150 & 0.85 & 5.57 & \multirow{2}{*}{11.29} & 4.31 & \multirow{2}{*}{8.74} & 3.51 & \multirow{2}{*}{6.27} & \\
\hline West Scupper & 15,442 & 0.95 & 7.32 & & 5.68 & & 4.62 & & \\
\hline North Trash & 61,625 & 0.95 & 5.57 & 7.49 & 4.31 & 5.79 & 3.51 & 4.72 & \\
\hline $\begin{array}{l}\text { Orange Street } \\
\text { (North) }\end{array}$ & 141,126 & 0.70 & 5.57 & 12.63 & 4.31 & 9.77 & 3.51 & 7.96 & \\
\hline $\begin{array}{l}\text { Orange Street } \\
\text { (South) }\end{array}$ & 23,856 & 0.70 & 5.57 & 2.14 & 4.31 & 1.65 & 3.51 & 1.35 & \\
\hline
\end{tabular}

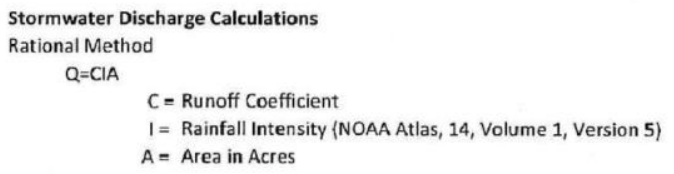

Figure 1-5: Stormwater Discharge Calculations prepared by Kland Engineering for Orange Mall highlighting the maximum discharge for Runnel D during a 25-yr storm.

Sanchez reported that during the study period, there were no storm events observed to exceed the capacity of the biodetention basins ${ }^{5}$. Because the engineer estimated the maximum discharge for "Runnel D" to be 11.36cfs (Figure 1-6), which would have only been sufficient to allow a 10-yr storm to pass through the basin without overtopping, Sanchez' data demonstrated that the site was able to manage a higher storm intensity than it was designed for, 13.24cfs or almost a 25-year storm. Additional soil moisture monitoring data and plant transpiration rate conducted by Sanchez provide evidence of the functions of soil and plants that helped to explain the increased stormwater holding capacity in the biodetention basins (see Limitations). 


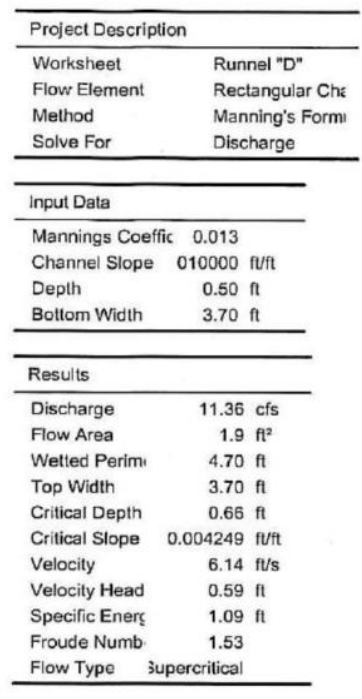

Figure 1-6: Stormwater Discharge Calculation for runnel D prepared by Kland Engineering for Orange Mall 4 as part of the drainage report. Runnel $D$ is estimated to manage a maximum of $11.36 \mathrm{cf} / \mathrm{s}$, or the equivalent of a 10 -year storm, though post construction performance assessment of the site demonstrates the runnel $D$ is able to manage at least $13.24 \mathrm{cf} / \mathrm{s}$, or the equivalent of a $25-y r$ storm.

\section{Sources:}

1. ASU History and Milestones https://www.asu.edu/about/university-history-and-milestones

2. ASU Majors and Degree Programs https://admission.asu.edu/academics/majors-degrees

3. US Climate Data - https://www.usclimatedata.com/climate/phoenix/arizona/united-states/usaz0166

4. Kland, Leslie. Letter to Arizona State University. "ASU Orange Mall Drainage Letter," February 2, 2017.

5. Sanchez, Christopher A. "Designing and Implementing Ecological Monitoring of Aridland Urban Ecological Infrastructure (UEI) : a Case-Study of Design Process and Outcomes ." Arizona State University, 2019.

6.. Wood, Patel, \& Associates Inc. Letter to Arizona State University. "Drainage Report for Arizona State University Tempe Campus SRC Fields Stormwater Retention." Tempe, Arizona, November 4, 2011.

\section{Limitations:}

1. Since this is a retrofit project to an existing drainage area and the consultant did not include the larger watershed drainage area in the calculation, the added on-site stormwater capacity may overlook the runoff derived from outside the site boundary. Thus it limits the understanding of the effects from the 2-acre pilot area in mitigating floods for 18-acre drainage areas.

2. Soil moisture and transpiration data were also collected in Sanchez's thesis. A range from $19 \%$ to $76 \%$ increase in plant transpiration varied by plant species after storms were recorded and demonstrated that biological functions contributed to the management of stormwater on site. There was a demonstrated increase in soil moisture according to the data during the storm events, indicating infiltration activity. However, the thesis did not use a complete water budget in the biodetention basins thus limiting the understanding of hydrological functions of the Gl design. 


\section{- Saves an estimated 1,000 gallons of water annually by using building-generated air conditioner condensate as supplemental irrigation.}

Background: The Orange Mall GI Project coincided with the construction of a new Net-Zero Student Pavilion, awarded LEED platinum certification in 2019. This building serves as a multiuse event space on the ground floor and houses offices for student government and cultural/ethnic identity-based student organizations, along with other university organizations and programs on the second and third floors. A prominent feature at the building's entrance is a series of descending copper-colored pipes that deliver building air conditioning condensate directly into the landscape for irrigation and aesthetic value. This feature was designed by Colwell Shelor Landscape Architecture to suggest the geology of Arizona caverns and caves.

Method: According to Weddle Gilmore Black Rock Studio, one of the architects of the building, there were never formal calculations completed on the volume of condensate to be produced from the building's air conditioning units for conveyance through this featured designed by the project landscape architect. These calculations are highly variable based on the activities occurring inside the building, internal occupancy conditions, along with outdoor air temperature and humidity conditions - which would dictate how the air conditioning units operate (Figure 21). Instead, HGA Architects \& Engineers (the other architect for the building) used estimates of the assumed activity and occupancy conditions of the building along with past geographic temperature and humidity data to estimate volumes of air conditioning condensate that the building might produce.

Calculations: The architects anticipated that condensate would likely make it to the landscape only during the peak summer months of June-September, an average between 90-120 days, when the indoor occupancy is full and the dew point is above $55-60^{\circ} \mathrm{F}$. It was estimated that some amount of condensate volume/flow would be collected for $+/-2,260$ hours or $25 \%$ of the year $(8,760$ hours per year / 2,260 hours $=0.258$ ) (Figure 2-2) and the other $75 \%$ of the year the feature would remain dry. According to the estimated flow rate calculations approximately 1,000 gallons/year of condensate was anticipated to make it to the landscape. 

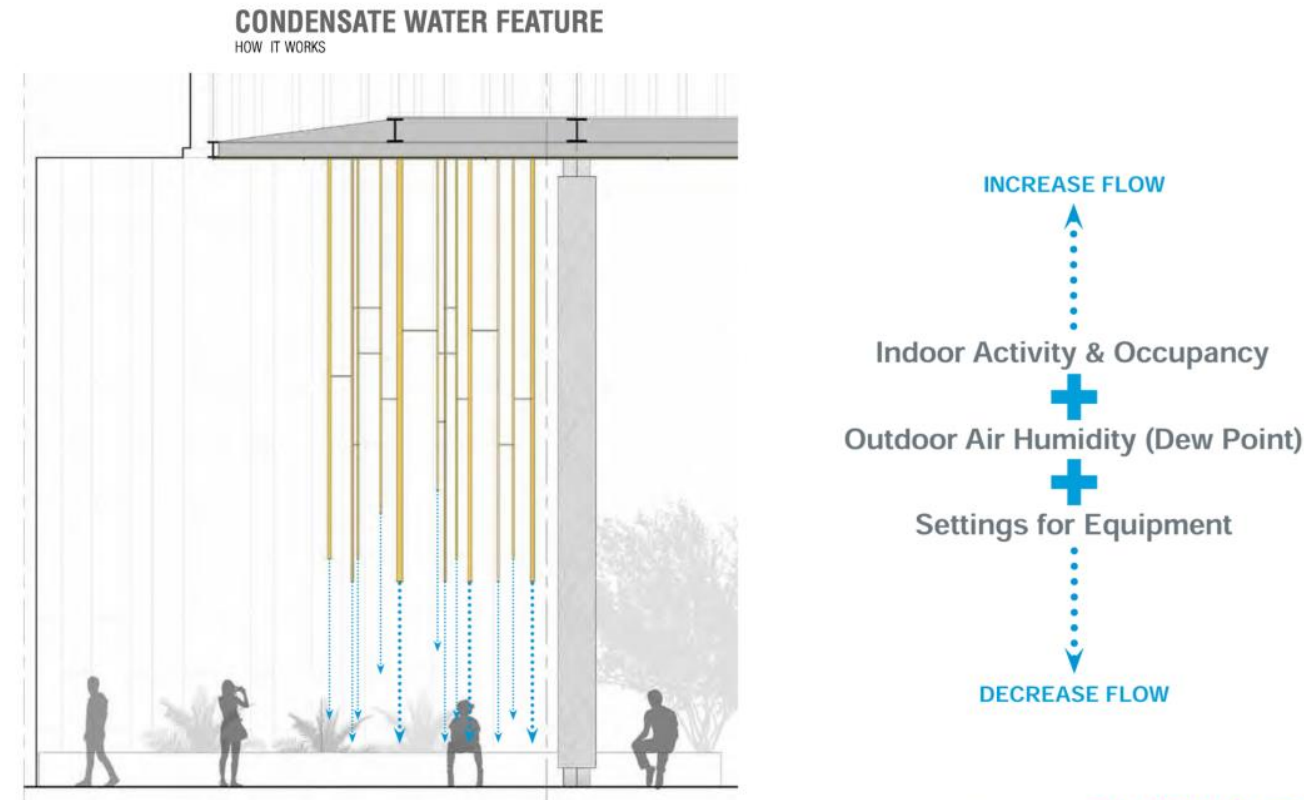

factors affecting . CONDENSATE FLOW

Figure 2-1: Conceptual framework for condensate flow calculation prepared by Weddle Gilmore Black Rock Studio, provided by Colwell Shelor Landscape Architecture.

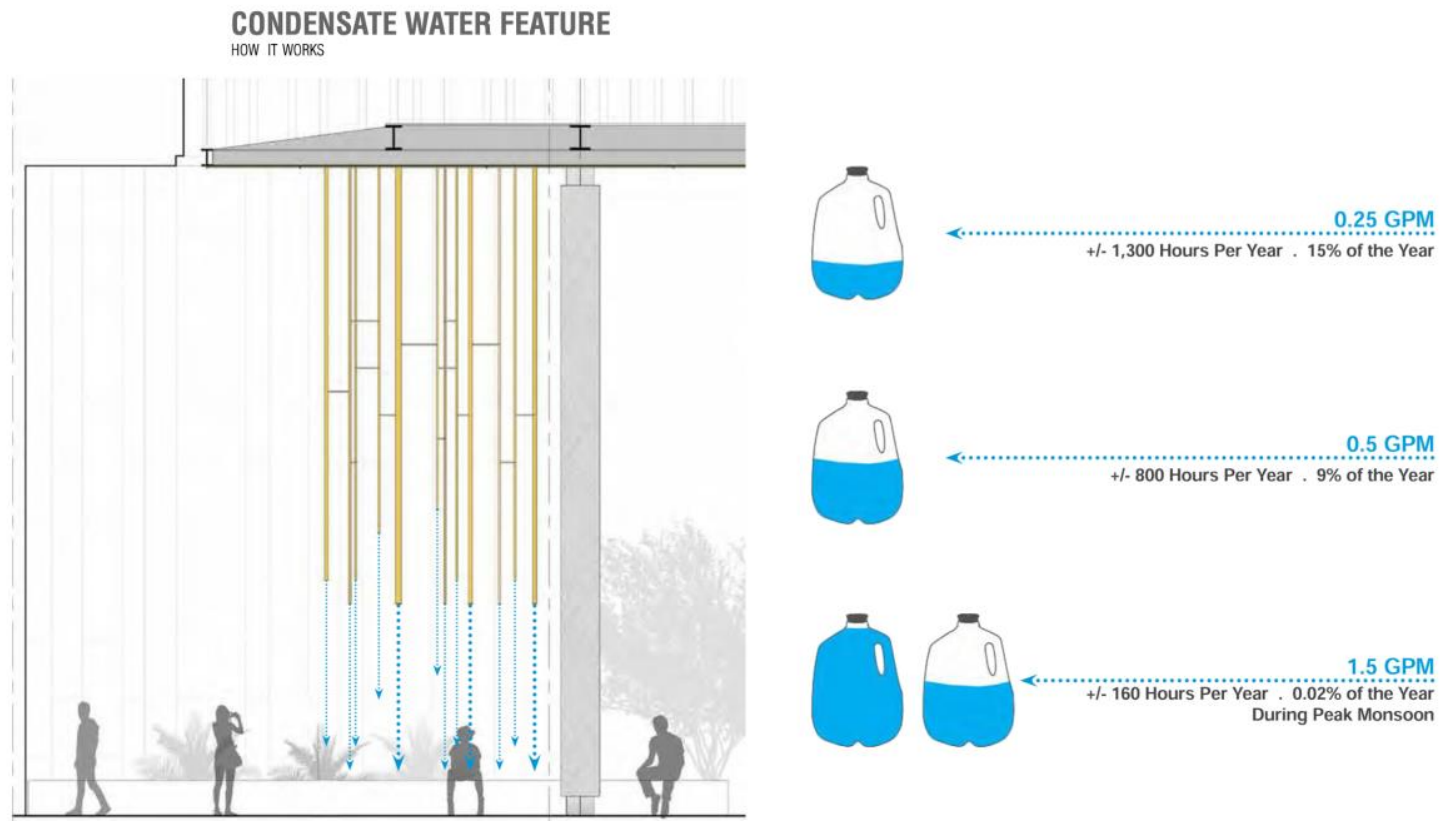

volume of water. CONDENSATE FLOW

Figure 2-2: Illustration of estimated volume of water from condensate flow with samples of conditions of the year prepared by Weddle Gilmore Black Rock Studio.

Source: Jeffrey DeHaven - Weddle Gilmore Black Rock studio, architect for Student Pavilion at ASU (email correspondence with Amanda Trakas) 
Limitations:

1. There is expected variability in the estimated activity and occupancy conditions inside the building along with external weather conditions. There is no monitoring record for this device to fully understand the volume of water generated from this intervention. According to Weddle Gilmore Black Rock Studio, there was debate as to how accurate a meter would be with such minimal predicted flows and no way to account for evaporation occurring between the meter and point of discharge. The assumption of the benefit of this feature is to reuse the condensate flow for other water use such as irrigation. However, there is no monitoring for irrigation water use; therefore, no benefits for reduction for irrigation use can be claimed.

\section{- Improves water quality with net reduction in total phosphorus of stormwater as it passes through the bioretention basins.}

Method: In order to understand the degree to which Gl design can affect the quality of stormwater runoff before and after flowing through the biodetention basins, five ISCO $\circledast 6712$ automated pump samplers were set up across the site. Each sampler is capable of collecting up to 9 discrete stormwater samples, which were recorded during storm events between August 2018 and March 2019 by Sanchez. ISCO samplers were installed at the inflow and outflow of the western half of the site, and at the inflow, mid-point, and outflow of the eastern half of the site $^{1}$ (Figure 3-1).

The samplers were programmed to draw samples only after a sufficient volume of stormwater flowing between connected biodetention basins activated the sensors. The samplers were also programmed to sample at non-uniform fixed time intervals, with sampling occurring more frequently during the beginning of storms when water quality was expected to change most rapidly. Stormwater samples were collected from the Orange Mall ISCOs within 12 hours of each event and transported to the ASU Wetland Ecosystem Ecology Lab for processing and then transported to the ASU Goldwater Environmental Lab for analysis. Stormwater samples were collected for dissolved organic carbon (DOC) and anion analysis along with total nitrogen (TN) and total phosphorus (TP). Nitrate (NO3-), nitrite (NO2-) and ammonium ( $\left.\mathrm{NH}_{+}+\right)^{1}$.

Calculations: There were limited opportunities for stormwater sampling during the study period because the majority of storm events resulted in little flow between the basins, failing to trigger the ISCO samplers. Despite the small sample size, the stormwater quality data collected did provide insight into quality improvement capacity of the site.

A pattern of net reduction of TP was documented as water moved through the basin system suggesting an effective capture of suspended solid particulate matter, as TP is often particulatebound $^{1}$. Less consistent however, were the monitored trends in the other types of nitrogen containing compounds (TN, NO3, and $\mathrm{NH} 4$ ) (Figure 3-1). 

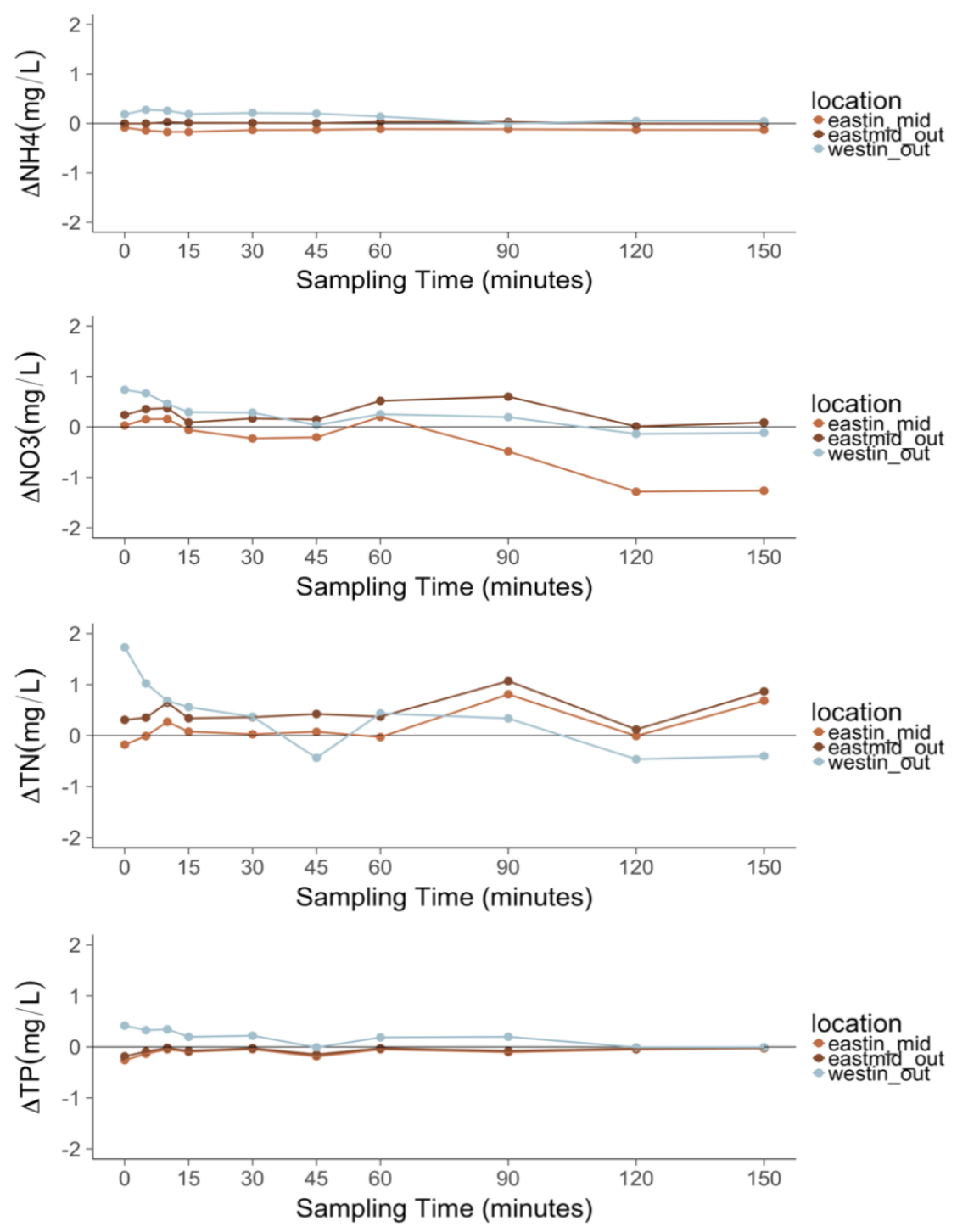

Figure 3-1: Average change in water quality concentrations between east basin inflow to midpoint ("eastin_mid"), east basin midpoint to outflow ("eastmid_out") and west basin inflow and outflow ("westin_out") From top to bottom: total nitrogen, ammonium, nitrate, and total phosphorus (from Sanchez 2019) ${ }^{1}$

\section{Sources:}

1. Sanchez, Christopher A. "Designing and Implementing Ecological Monitoring of Aridland Urban Ecological Infrastructure (UEI) : a Case-Study of Design Process and Outcomes." ${ }^{1}$ Arizona State University, 2019

\section{Limitations:}

1. Sanchez noted that the inconsistency in monitored nitrogen trends may be due to the hydrology of the system. The highly dispersed inflows from surface and roof flows may provide pathways for organics and other pollutants to enter the system at any point. 


\section{- Mitigates flooding by increasing on-site stormwater management capacity, lowering the high water elevation during a 100-year storm event by 1 inch.}

Method: In the drainage letter to Arizona State University, the project civil engineer calculated a maximum discharge rate for each biodetention basin for different storm intensities using the rational method and NOAA Atlas 14 , vol 1 , vers 5 for intensity ${ }^{1}$.

Calculations: Using Haestad FlowMaster v7.0, existing and proposed conditions were modeled to determine the stormwater inundation surface elevation during the 100-year storm event. The projected water depth during a 100-yr storm event of .32 ft (3.84 inches) was improved to $.24 \mathrm{ft}$ (2.88 inches) $)^{1}$ through the site with the simulation of the proposed design compared to existing conditions.

Sources:

1. Kland, Leslie. Letter to Arizona State University. "ASU Orange Mall Drainage Letter," February 2, 2017.

\section{Limitations:}

1. The civil engineer used a hydrological simulation model for calculating stormwater runoff hydraulics and volumes. The letter provided for this project did not include detailed methods and results and the stated summary results are not compatible with the rational method.

2. Not independently verified by the CSI research team.

- Reduces mean radiant temperature by $22-24^{\circ} \mathrm{F}$ in areas that received added shade and by $4^{\circ} \mathrm{F}$ in areas that did not receive added shade, as measured on a sunny afternoon, compared to adjacent areas with conditions similar to the site before the redesign.

Background: The Orange Mall GI Project converted a portion of Orange Street into a pedestrian-centered extension of Orange Mall. Shade and materiality are essential considerations in the design of pedestrian-centered outdoor spaces, especially in hot desert cities $^{1}$, when considering human thermal comfort. Though thermal comfort is a complex and subjective representation of site conditions ${ }^{2}$, the exchange of thermal radiation between an individual and their surroundings is a prominent component, along with air temperature, wind speed, and relative humidity ${ }^{2}$. A globe thermometer is employed to measure these factors, which combined are expressed as the Mean Radiant Temperature (MRT) of a specific location. This measurement, taken at about chest height of an average adult, provides a more accurate representation of the outdoor temperature perceived by a person at a specific location rather than using air temperature alone ${ }^{1}$. 


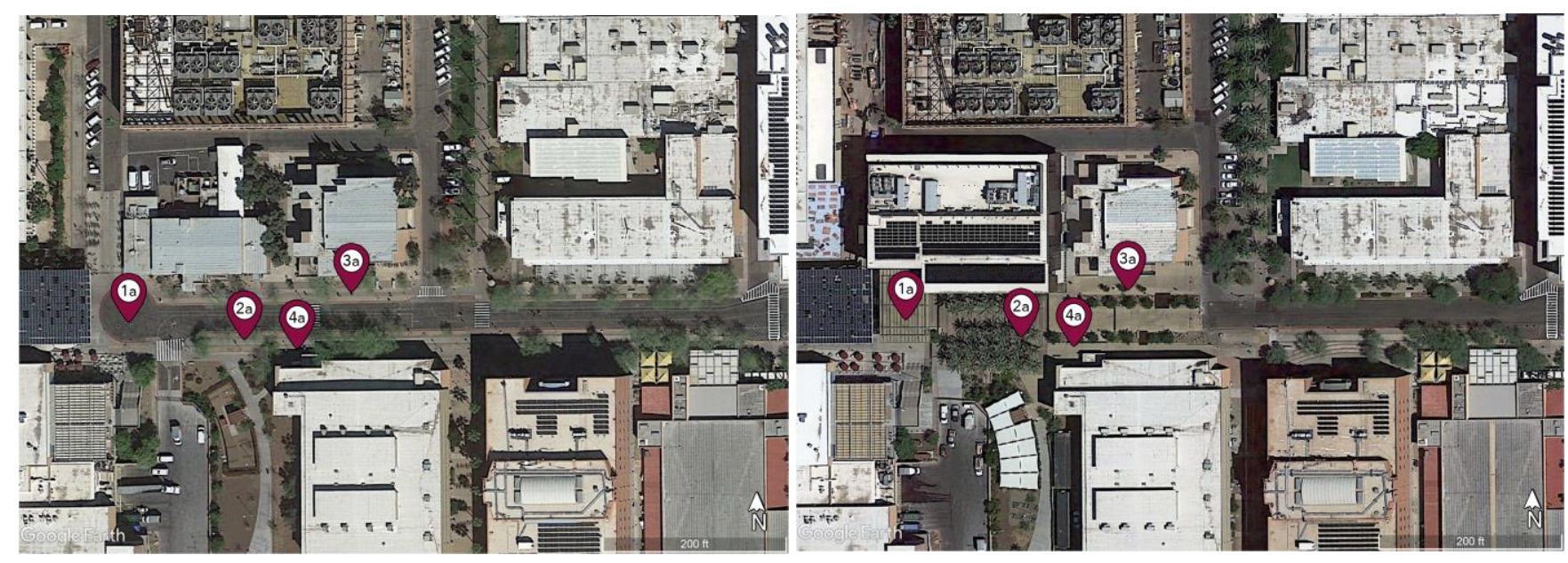

Google Earth

Figure 4-1: Locations where MRT was recorded on the Orange Mall to represent both pre- (2016 - left) and post(2019 - right) design intervention to be compared to selected locations serving as a control sample on the remaining Orange street roadway adjacent to the site.

Method: MRT was calculated based on globe thermometer measurements at a total of eight locations within the new Orange Mall GI Project and on the remaining Orange street roadwaywhich acts as a control - representing the converted portion of Orange Street before redesign. The "a" markers are shown both on the site in 2016 and in 2019 representing the locations where measurements are taken on site and the conditions to be replicated on the remaining roadway for measurement (Figure 4-1). Locations on the site and the existing remaining roadway were chosen based on their similarity in surrounding building and paving material characteristics to represent site conditions for pre- and post- design intervention. Preconstruction conditions were measured at the gold "b" markers on the remnant roadway (Figure 4-2). These represent (1) an asphalt cul de sac, (2) center of the site, (3) a sunny location near streetscape in front of a campus building, and (4) a shady location near streetscape in front of a campus building. Measurements at each location were taken using two Kestral 440 Heat Stress Meters at "a" and "b" locations from 12pm-1pm on June 23, 2020. Measurements at corresponding locations were taken simultaneously, with two researchers coordinating both calibration time for the thermometer and recording a temperature reading at the same time. 

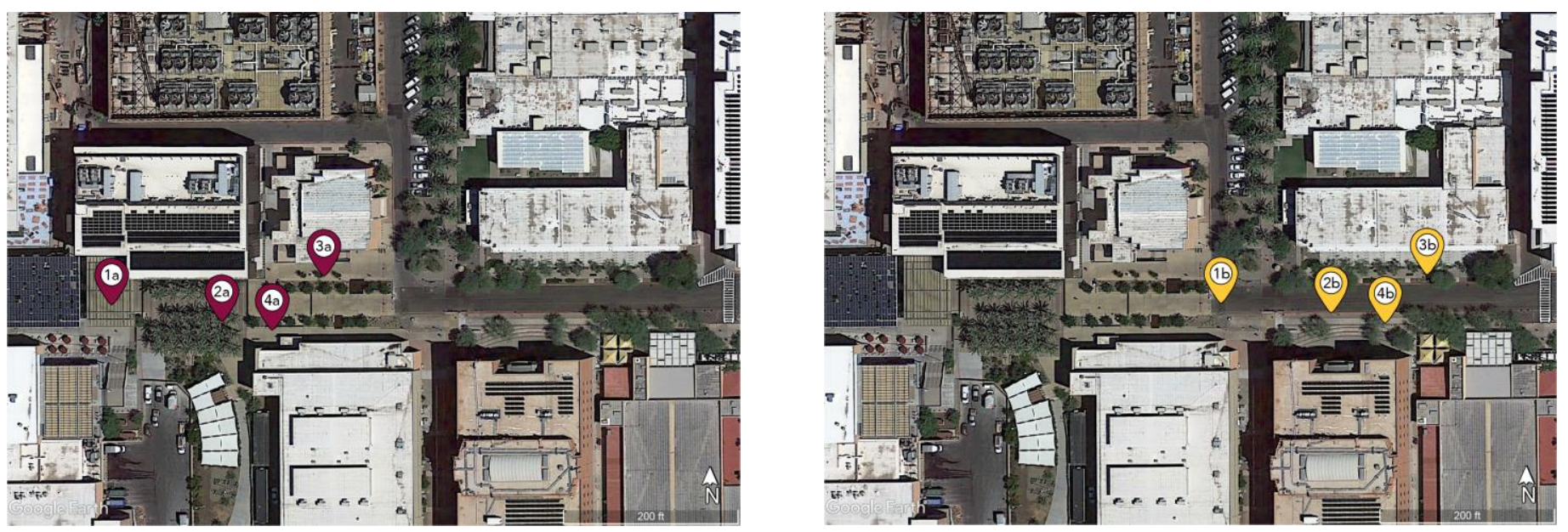

Google Earth

Figure 4-2: Eight locations where globe temperature measurements were recorded simultaneously to represent preand post- design intervention conditions on Orange Mall. Maroon markers represent the current site conditions while gold markers represent the control locations on site pre-design intervention.

Calculations: Globe temperature was measured with two Kestral 440 Heat Stress Meter (Figure 4-3) at the designated pre- and post-design locations. Using these measurements, MRT was then calculated (Figure 4-4) in an excel spreadsheet.
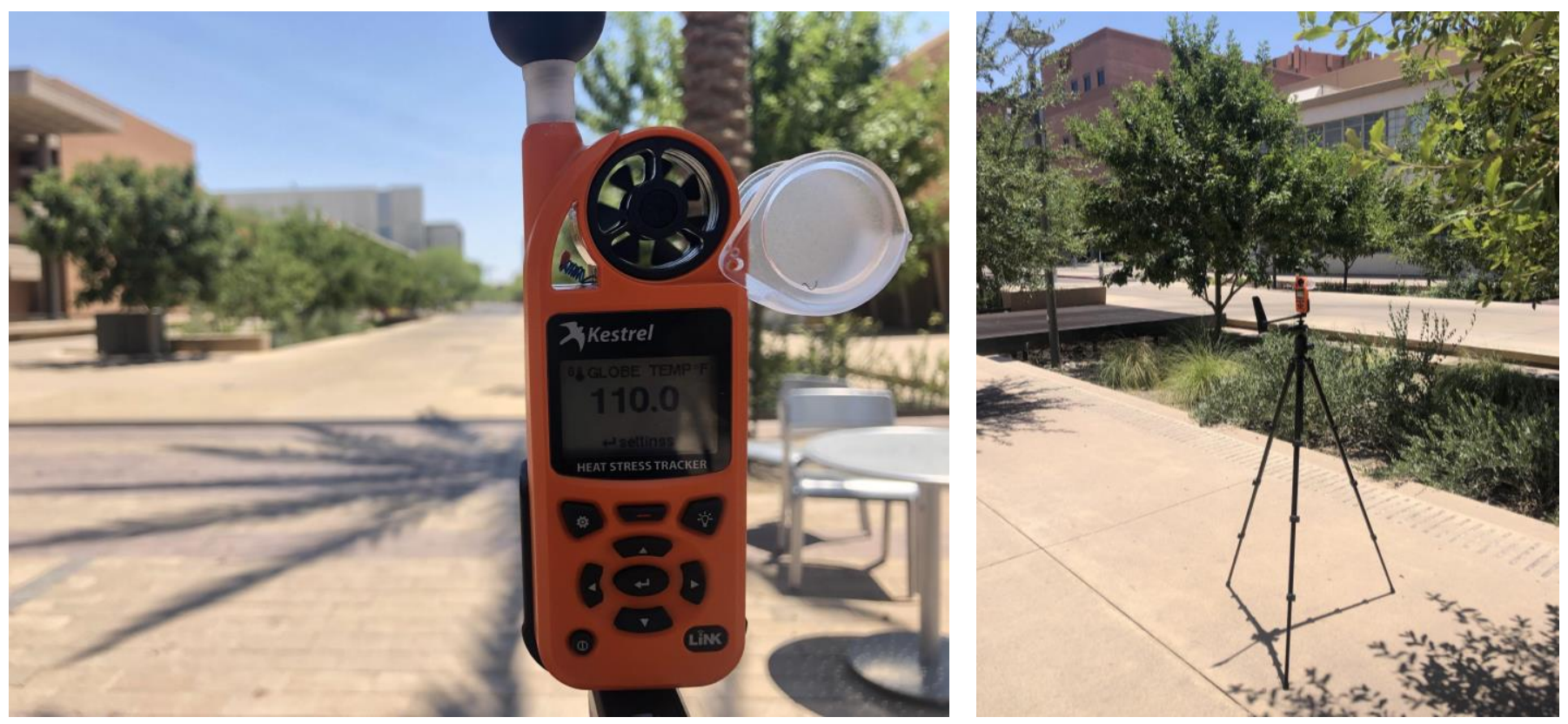

Figure 4-3: Kestrel 440 Heat Stress Meter used to calculate MRT on Orange Mall 


$$
T_{m r t}=\left[\left(T_{g}+273.15\right)^{4}+\frac{1.1 \cdot 10^{8} V_{a}^{0.6}}{\left(\varepsilon D^{0.4}\right)\left(T_{g}-T_{a}\right)}\right]^{0.25}-273.15
$$

Figure 4-4: MRT Formula that uses measurements taken by a globe thermometer, or the Kestral 440 Heat Stress Meter. $^{1}$

Tmrt is the mean radiant temperature, $\mathrm{Tg}$ is the globe temperature, $\mathrm{Ta}$ is the air temperature, $\mathrm{Va}$ is the air velocity, eD the diameter of the globe.

\begin{tabular}{|c|c|c|c|c|c|c|c|c|c|c|}
\hline \multirow{3}{*}{ Location $1 \mathrm{a}$ and $1 \mathrm{~b}$} & \multicolumn{2}{|r|}{$\begin{array}{l}\text { Wind Speed } \\
\text { mph }\end{array}$} & \multirow[t]{2}{*}{$\begin{array}{l}\text { Wind Speed } \\
\mathrm{m} / \mathrm{s}\end{array}$} & $\begin{array}{l}\text { Temperature } \\
-\infty \mathrm{F}\end{array}$ & $\begin{array}{l}\text { Temperature } \\
\mathrm{C}\end{array}$ & \multicolumn{2}{|c|}{$\begin{array}{l}\text { Globe Temperature Globe Temperature } \\
\begin{array}{l}\text { C } \\
\text { C }\end{array}\end{array}$} & \multicolumn{2}{|c|}{ MRTC MRTF } & \multirow[t]{2}{*}{ Difference of a-b MRT F } \\
\hline & & & & & & & & & & \\
\hline & 6/23/20 12:14 1a (shade) & 0 & 0.00 & 101.6 & 38.7 & 104.8 & 40.4 & 40.44 & 104.8 & -24.4 \\
\hline & $6 / 23 / 2012: 141 \mathrm{~b}$ (sun) & 0 & 0.00 & 103.1 & 39.5 & 129.2 & 54.0 & 54.00 & 129.2 & \\
\hline \multicolumn{11}{|l|}{ Location $2 \mathrm{a}$ and $2 \mathrm{~b}$} \\
\hline & 6/23/20 12:24 2a (shade) & 1.3 & 0.58 & 103.4 & 39.7 & 110 & 43.3 & 43.70 & 110.7 & -22.1 \\
\hline & $6 / 23 / 2012: 242 b$ (sun) & 1.9 & 0.85 & 104.4 & 40.2 & 129.8 & 54.3 & 55.98 & 132.8 & \\
\hline \multicolumn{11}{|c|}{ Location $3 \mathrm{a}$ and $3 \mathrm{~b}$ (sun) } \\
\hline & 6/23/20 12:33 3a (sun) & 0 & 0.00 & 105.1 & 40.6 & 133.7 & 56.5 & 56.50 & 133.7 & -4.4 \\
\hline & $6 / 23 / 2012: 333 \mathrm{~b}$ (sun) & 1.6 & 0.72 & 101.6 & 38.7 & 134.8 & 57.1 & 58.97 & 138.1 & \\
\hline \multicolumn{11}{|c|}{ Location $4 \mathrm{c}$ and $4 \mathrm{~d}$ (shade) } \\
\hline & 6/23/20 12:56 3a & 2.6 & 1.16 & 102.6 & 39.2 & 115.7 & 46.5 & 47.64 & 117.8 & -5.0 \\
\hline & $6 / 23 / 2012: 55$ 3b & 1.1 & 0.49 & 104.9 & 40.5 & 121.4 & 49.7 & 50.43 & 122.8 & \\
\hline
\end{tabular}

Table 1: MRT results

Location 1 represents the asphalt cul de sac which was converted to a shaded entry to the Student Pavilion, this modification to the site provided a cooling of $24.4^{\circ} \mathrm{F}$. Location 2 represents the middle of the site, measurement $2 a$ was taken under the shade of the mature palm grove white $2 \mathrm{~b}$ was taken on the asphalt roadway. The removal of asphalt, addition of pavers and mature palm trees contributed to a $22.1^{\circ} \mathrm{F}$ cooling of the middle of the site. Locations 3 and 4 reported more modest temperature reductions as these locations compared sun to sun and shade to shade conditions. Location 3 compared two sunny locations near the streetscape in front of a campus building. Measurement 3a was recorded on Orange Mall with new concrete paving within proximity to a bio detention basin while $3 \mathrm{~b}$ was recorded on near the standard streetscape adjacent to an asphalt roadway. There was a $4.4^{\circ} \mathrm{F}$ improvement on Orange Mall again most likely due to the removal of the asphalt roadway and the additional vegetation provided by the biodetention basin. Measurement 4 saw similar results with $5^{\circ} \mathrm{F}$ improvement in MRT taken at the south end of the site, near streetscape and in front of a campus building, only in the shade.

\section{Sources:}

1. Middel, Ariane \& Selover, Nancy \& Hagen, Bjoern \& Chhetri, Nalini. (2016). Impact of shade on outdoor thermal comfort-a seasonal field study in Tempe, Arizona. International Journal of Biometeorology. 60. 10.1007/s00484-016-1172-5.

2. Thorsson S, Lindberg F, Eliasson I, Holmer B (2007) Different methods for estimating the mean radiant temperature in an outdoor urban setting. Int J Climatol 27(14):1983-1993. doi:10.1002/joc.1537

\section{Limitations:}

1. The original research plan was to take measurements at each of the designated 
locations at $8 \mathrm{am}, 12 \mathrm{pm}$, and $4 \mathrm{pm}$ for a broader understanding of how temperature across the site is felt throughout the day. However, Arizona State University campus was closed due to the COVID-19 pandemic and access to campus buildings is prohibited. Because shelter from the elements during breaks was not available, only the afternoon measurements were taken.

2. Additionally, MRT only accounts for about $50 \%$ of thermal sensation while the other $50 \%$ is determined by personal, non-meteorological, factors including adaptation, temperature preference, gender, season, and time of day ${ }^{1}$. Although the post-design conditions of the Orange Mall GI Project were found to be cooler than pre-design by the measurements taken, there is variability as to how these conditions would be experienced by different individuals.

- Diverted $99.9 \%$ of demolition materials from the site and buildings from the landfill through recycling, repurposing, and composting.

Background: Orange Mall was constructed in concert with the Net Zero LEED Platinum Student Pavilion. Careful documentation of the demolition of the existing site and building of the new building and landscape were necessary to fulfill the requirements of these certifications.

Method: To fulfill the MRc2 credit for LEED, a zero waste plan was put together by the building architects in cooperation with the landscape architect and other contractors on site. For the construction of Orange Mall large portions of existing asphalt and concrete along with existing landscape material had to be removed (Figure 5-1). These materials were either repurposed, recycled, or composted and diverted from the landfill (Figure 5-2).
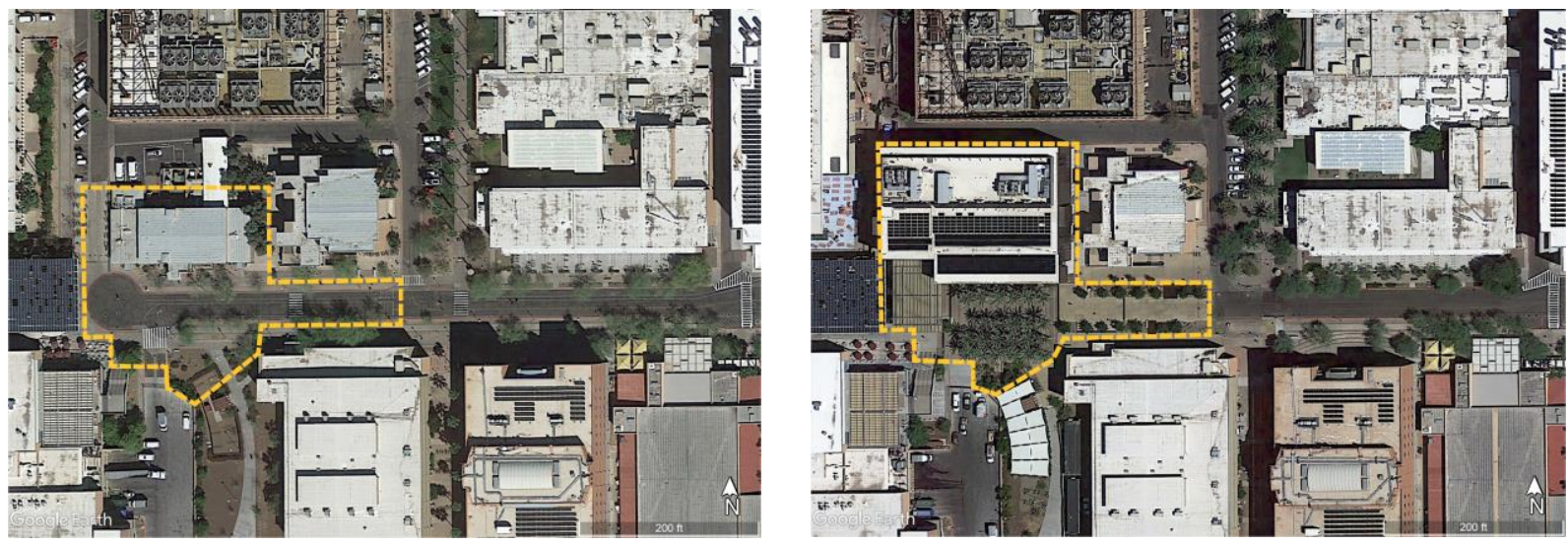

Figure 5-1: Satellite imagery of the pre-construction (2016) and current (2019) conditions of Orange Mall illustrate the large quantities of asphalt, concrete, and landscaping materials that were removed. 


\section{Calculations:}

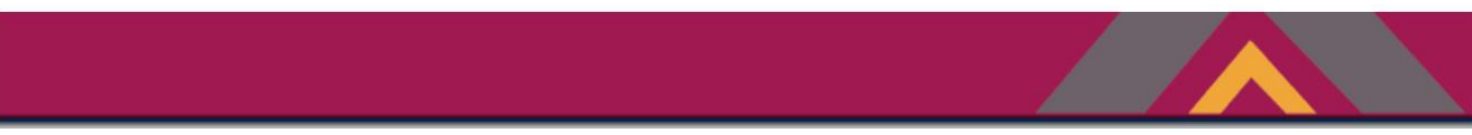

\section{Zero Waste \\ Reduce | Reuse | Recycle}

UASB Demolition-Zero Waste Plan

\section{EDGE}

\section{ASU Project \#11379}

\begin{tabular}{|c|c|c|c|}
\hline MATERIAL & NEW USE & RECIPIENT & WEIGHT (TONS) \\
\hline Office Items and Appliances & ASU Surplus - for use or sale & ASU Surplus & 5.25 \\
\hline Carpet & Repurposed for floor protection at UPOS & $\mathrm{U}$ of $\mathrm{P}$ Stadium & 5.4 \\
\hline Acoustical Ceiling Tile & Reused/Recycled into new ACT & WinRoc & 2.9 \\
\hline Drywall & Ground for Mulch & Growell & 34.9 \\
\hline Metal - Ferrous \& non-Ferrous & Recycled \& Reused in new products & Liberty Metals & 81.3 \\
\hline Insulation \& Vinyl Baseboard & $* *$ Landfill & Weinburger & 2.96 \\
\hline Wood & Ground for bedding & No Waste Grindings & 11.7 \\
\hline \multirow[t]{2}{*}{ Trees } & Used for bowls & ASU Personel & 3.5 \\
\hline & Ground for wood chips & No Waste Grindings & 4.9 \\
\hline Bulbs & ASU EH\&S & ASU EH\&S & 0.065 \\
\hline Ballasts & ASU EH\&S & ASU EH\&S & 0.11 \\
\hline Rigid Plastics & Recycled \& Reused in new products & No Waste Grindings & 3.3 \\
\hline Glass Doors/storefront & Repurpose in future & ASU Surplus & 0.8 \\
\hline Glass & Ground for $A B C$ or road base & Johnson Stewart & w/concrete \\
\hline Mechanical units & Dismantle and Recycle & Liberty Metals & 4.4 \\
\hline Freon from units & Drained and Reused & Briston Mechanical & $n / a$ \\
\hline Hydraulic Oil @ Elevator & ASU EH\&S & ASU EH\&S & 0.165 \\
\hline Concrete & Ground for $A B C$ or road base & Johnson Stewart & 3187.4 \\
\hline Copper & Recycled for new copper & Liberty Metals & 1.7 \\
\hline Brick & Ground for $A B C$ or road base & Johnson Stewart & w/concrete \\
\hline \multirow[t]{4}{*}{ Asphalt } & Used for millings, dust control, or road base & Johnson Stewart & 96.6 \\
\hline & Total Weight of UASB (tons) & & 3447.4 \\
\hline & **Landfill Tonage & & 2.96 \\
\hline & Diversion Rate & & $99.914 \%$ \\
\hline
\end{tabular}

Figure 5-2: Demolition - Zero Waste Plan for ASU Student Pavilion documenting by weight, materials that were removed from the existing site though diverted from the landfill, provided by Jeffery DeHaven of Weddle Gilmore.

\section{Sources:}

1. ASU Student Pavilion LEED Credit Submittal - Sent by Jeffery DeHaven of Weddle Gllmore Black Rock Studio via email to Amanda Trakas on April 6, 2020. 
Limitations:

1. Although the landfill diversion of demolition materials was submitted to satisfy both LEED and SITES credits, it is impossible to differentiate the exact quantity of diverted material from the landscape alone.

\section{Social Benefits}

- Provides opportunities for socializing and relaxation for an average of 400 daily site users who spend at least 2 hours on site as observed on typical days during 3 consecutive semesters from spring 2018 to spring 2019.

Background: ASU is one of the largest universities in the country, with over 50,000 students attending the Tempe campus alone. ${ }^{1}$ The pedestrian malls on campus, including Orange Mall, host many thousands of students daily as they attend classes, work, or seek university services. Orange Mall connects the west side of campus directly to the Memorial Union (Figure 6-1), one of the busiest buildings on campus offering the majority of campus dining options, banking, meeting space, lounges and study spaces, copy center, and market $^{2}$ (Figure 6-2).

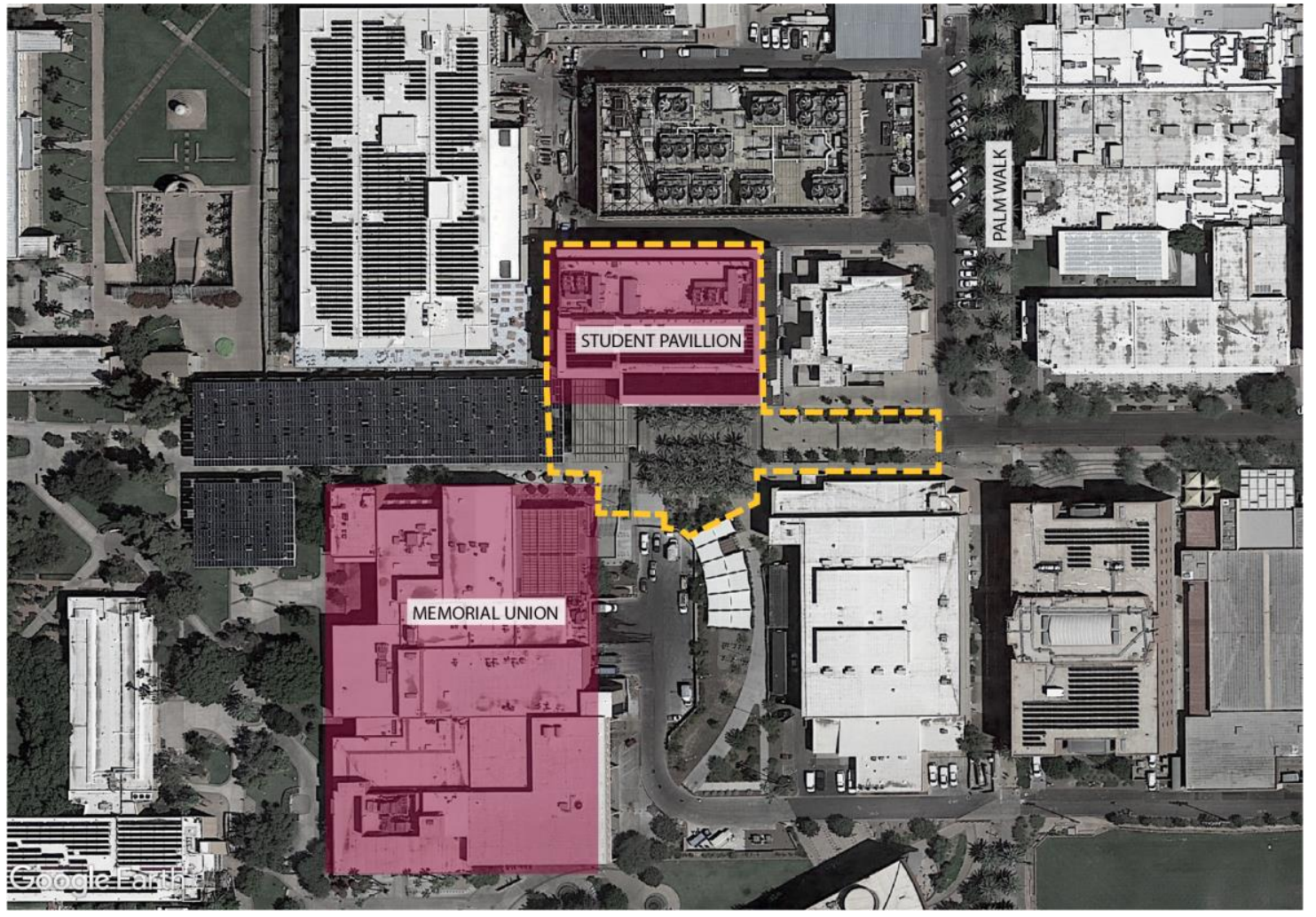

Figure 6-1: Location of Orange Mall and Student Pavilion directly adjacent to the Memorial Union (MU). Orange Mall hosts many of the students who travel to and from the MU daily on the Tempe campus. 


\section{Door Counts for Memorial Union 2018}

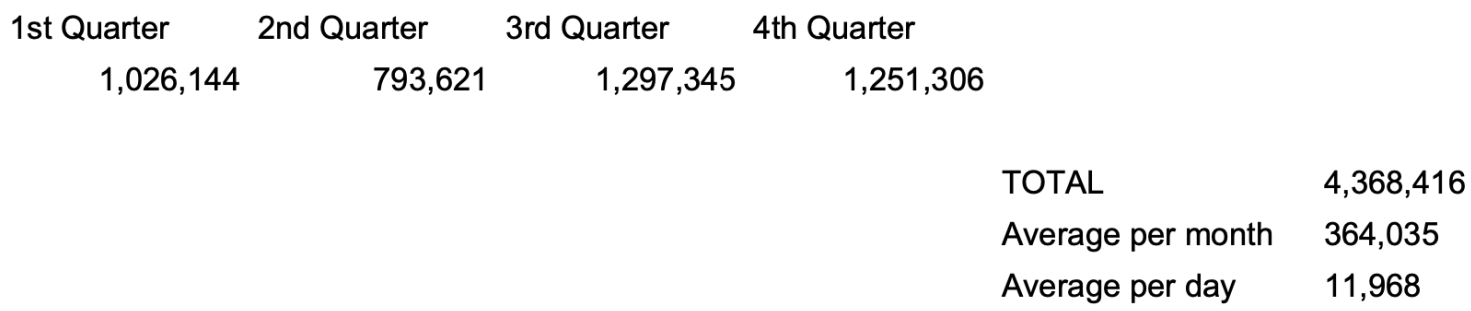

Figure 6-2: Door counts from the MU in 2018 provided by Joshua Diaz, Coordinator Senior at Memorial Union (MU). The MU is the busiest building on the ASU Tempe campus and averaged almost 12,000 daily visitors in 2018 to which Orange Mall is a direct east-west link.

Method: The number of daily site users was taken from student observations during three consecutive semesters from spring 2018 to spring 2019 in a course called ALA 102 Landscapes and Sustainability. These observations were prepared for the Sustainable SITES certification credit on Human Health and Well Being, with a specific focus on site users engaging in mental restoration and social connection activities. Students were tasked to observe activities on Orange Mall in 30-minute intervals, counting the site users and taking notes on their activities and any interaction with different site elements.

\section{Calculations:}

The following calculations were taken from Credit 6.6 of the SITES documentation submitted for Orange Mall (Figure 6-1). The output is an estimation of the number of site users who spend more than two hours on-site. SITES requirements state that number of site users be those who spend 2+ hours per day on site. These calculations use data collected by student observations on site and the SITES equation:

Total number of Site Users on Orange Mall= [2096 (number of users per 30 minutes at the peak of the school day) +1720 peak transients] ${ }^{*} 10 \%$ (percent of those users who are estimated to be onsite for more than 2 hours) $=381.6+32 \mathrm{FTE}=414$ total users (Figure 6-1) .

FTE refers to the number of Full Time Equivalent staff members at the Student Pavilion (from LEED) 


\begin{abstract}
Areas created to support mental restoration within the Orange Mall project are set back from the main pedestrian walkways while maintaining an ease of accessibility to site users. With an average of $\mathbf{4 1 4}$ site users daily on this busy campus mall, creating a diversity of spaces was paramount to accommodate the needs of students and campus visitors. Along with creating a sense of enclosure from above and anchoring the site to the south, these areas are shaded both by desert vegetation as well as the emblematic date palms located at the center of the site. They also offer bench or movable seating for more than $\mathbf{4 0}$ site users seeking quieter spaces which are within the closest proximity to the landscape. Vegetation is used in these areas to create a serene environment that encourages wildlife while mitigating the distractions of pedestrian traffic on the main walkways.
\end{abstract}

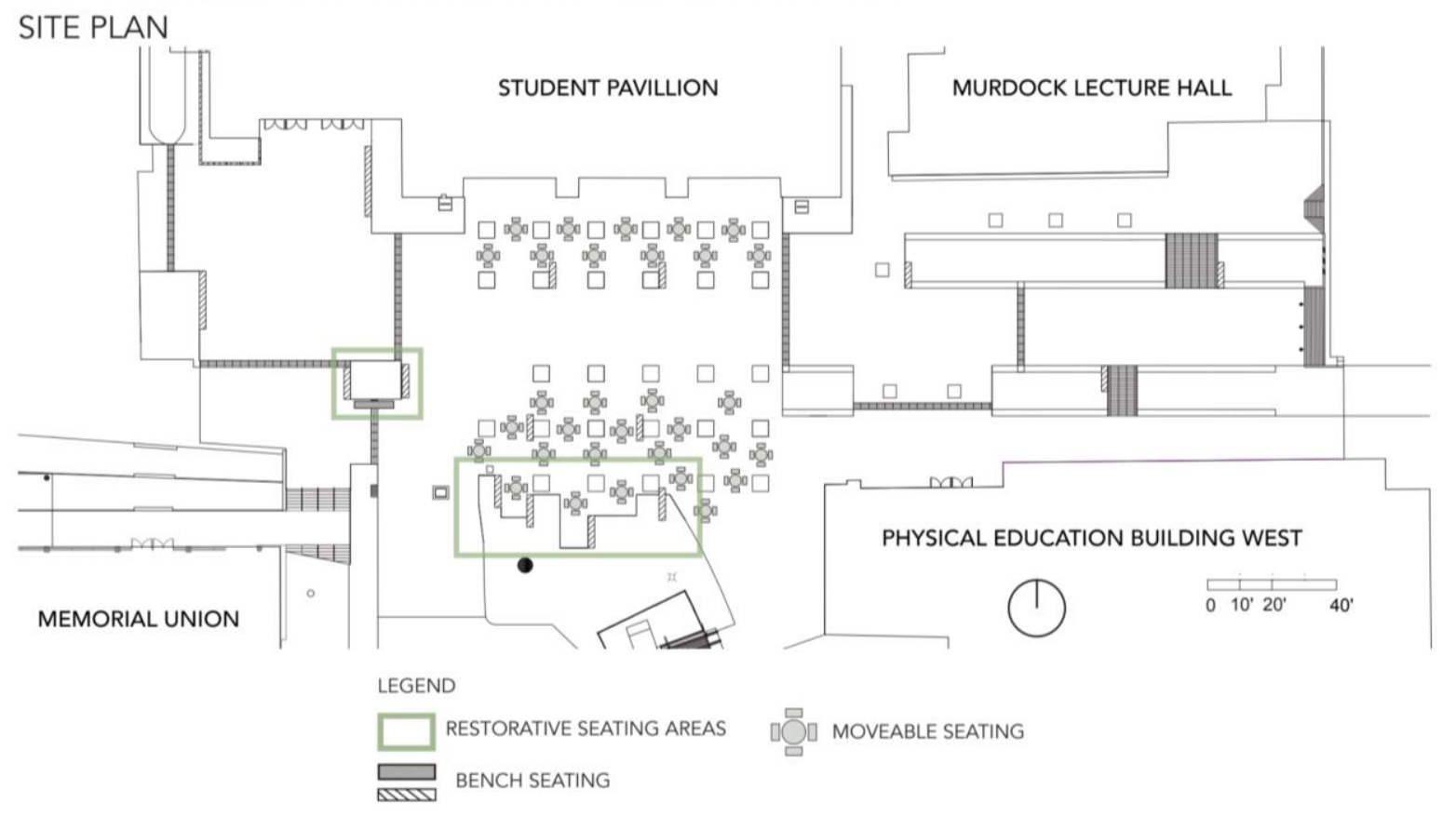

Figure 6-1: SITES Documentation - ASU Orange Mall Green Infrastructure Project compiled by Amanda Trakas and Chingwen Cheng. Final documentation provided by Cindy Quinn of Ecological Environments via email on April 3, 2020.

\title{
Sources:
}

1. ASU: Facts and Figures https://www.asu.edu/about/facts-and-figures

2. ASU: Memorial Union https://eoss.asu.edu/mu/whats in

3. Door Counts Memorial Union provided by Joshua Diaz, Coordinator Senior at. Memorial Union via email to Amanda Trakas on May 15, 2020.

4. Orange Mall GI Project Sites Documentation by Amanda Trakas and Chingwen Cheng

\section{Limitations:}

1. Student observation data used for SITES credit 6.6 recorded site visitors participating in social or restorative activities on site. This may have excluded site users participating in other activities and may misrepresent the total number of daily site users.

2. Although the door counts of Memorial Union may reflect the number of visitors Orange Mall receives annually, there is no mechanism in place to accurately count the number of individuals who pass through the site each day. The entry/exit door used in Memorial Union along with the destination of each individual captured in the count would have to be isolated to determine if they in fact would use Orange Mall as a path to/from/past the Memorial Union. 
3. Additionally, the SITES observation data is limited to the time observers conducted during the day (mostly during the lunch time between 11-2) and also limited to the beginning of the Fall and Spring semester (around mid-September and late January only) of the year, not including the hot summer days.

\section{- Provided educational value for 7 courses and 500 students within The Design School at Arizona State University in 2019. Students learned about the sustainable features and functions of the site.}

Background: The Design School at ASU offers degree programs in multiple design disciplines at both the undergraduate and graduate levels. Although the majority of students introduced to the features and functions of the Orange Mall site are within the Landscape Architecture program, the required undergraduate survey course Landscapes and Sustainability along with the undergraduate elective 20th Century Landscape Architecture History and graduate elective, Urban Water, broaden the scope of student exposure to the site.

Method: Courses that introduce and/or study the site features and functions of Orange Mall and their respective student counts were obtained by a survey of the Landscape Architecture faculty by the research assistant for the Orange Mall GI Project, Amanda Trakas for the CSOI.

For the survey, six Landscape Architecture faculty were contacted and able to respond on the number of courses and students that they taught/exposed to the designed stormwater management features of the Orange Mall GI Project on campus. Faculty were unaware of any other courses outside of the Design School that might feature the site. One School of Sustainability professor was also contacted, along with several Sustainability students - but none were found to study Orange Mall or know of anyone else who did.

\section{Calculations:}

\begin{tabular}{|c|c|c|c|}
\hline \multicolumn{4}{|l|}{ Fall } \\
\hline Course Number & Course Title & Students & Information Covered \\
\hline LDE $361 / 590$ & CoreLandscape Architecture Studio I & 30 & Bioswale design and water conveyance \\
\hline LDE 521 & Advanced Landscape Arch, Studio I & & 6 Sustainable stormwater management with additional community stakeholders \\
\hline LDE 598 & Urban Water & 7 & 7 Sustainable stormwater management \\
\hline LAP 352 & Ecosystems and Sustainable Design & 32 & 2 Site functions related to stormwater management \\
\hline \multicolumn{4}{|l|}{ Spring } \\
\hline LTC 466/LAP 598 & Landscape Construction III & 30 & Construction details and connections \\
\hline ALA 102 & Landscapes and Sustainability & 322 & 2 Guest lecture (Michele Shelor) stormwater management incorporated into design. \\
\hline LPH 311 & 20th Century Landscape Architecture History & 71 & $\begin{array}{l}\text { Project background including construction and highlight of site features. } \\
1 \text { Identification of supported social and ecological activity on site. }\end{array}$ \\
\hline
\end{tabular}

Figure 6-1: Table compiled by Amanda Trakas after email correspondence with faculty and staff at The Design School at Arizona State University showing the number of course that introduce features and functions of Orange Mall. 


\section{Sources:}

1. Email correspondence with The Design School faculty and staff (by Amanda Trakas)

Limitations:

1. The listed counts cannot represent the entirety of the educational value supported by the site as the educational use is not centrally documented. There may be additional university courses that feature the site, that were not found by the Research Assistant of this CSI that the site is part of in-person and virtual campus tours along with educational community and practitioner tours. For additional information on the broader educational impact of the Orange Mall GI Project at ASU, see Educational Impact tab in the Case Study Brief. 